\title{
Technological patterns in the wind power industry: a study based on patent deposits
}

\author{
Rafael Garcia Barbastefano* (D), Cristina Gomes Souzaa, Maria Clara Lippia, \\ Renata Cristina Teixeira ${ }^{b}$, Daniel Penalva Santos ${ }^{c}$ \\ ${ }^{a}$ Centro Federal de Educação Tecnológica Celso Suckow da Fonseca, Rio de Janeiro, RJ, Brasil

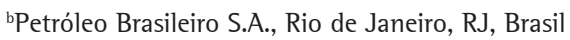 \\ Instituto Federal de Pernambuco, Recife, PE, Brasil \\ *barbastefano@gmail.com
}

\begin{abstract}
Paper aims: This paper presents the results of technological analysis on wind energy based on patent documents classified with code F03D - "Wind Motors."

Originality: Despite several studies on wind energy, this paper follows a different approach, presenting an overview that brings together technical and market information through social network analysis methods.

Research method: The study covered data from 55,223 documents filed in the principal patent offices of the world, obtained from the Derwent Innovations Index. The publications were organized and analyzed through correlation and technology transfer networks.

Main findings: General Electric (GE) and European companies have dominated the wind energy industry. However, in the last years, companies from emerging countries are also penetrating and becoming major players. Emphasis can be given to China, which has a deposit pattern detached from the rest of the world.

Implications for theory and practice: This study indicates that these companies became important turbine manufacturers and started to invest in developing new technologies and seek patent protection. Companies from emerging countries are new entrants, and their performance is still restricted to few markets compared to traditional companies.
\end{abstract}

Keywords

Wind energy. Renewable energy. Patent analysis. Technological monitoring.

How to cite this article: Barbastefano, R. G., Souza, C. G., Lippi, M. C., Teixeira, R., \& Santos, D. P. (2021). Technological patterns in the wind power industry: a study based on patent deposits. Production, 31, e20210051. https://doi. org/10.1590/0103-6513.20210051.

Received: May 29, 2021; Accepted: Sept. 20, 2021.

\section{Introduction}

The growing concern about sustainability and environmental regulations to comply with international agreements for the reduction of greenhouse gas emissions are factors that have stimulated the development and use of renewable energy sources (Hao \& Shao, 2021). This issue has attracted society, governments, academia, public and private organizations, and other stakeholders worldwide (Lanshina et al., 2018). Currently, many countries have policies and targets for renewable energy (Hille et al., 2020).

There are three major types of renewable energy: hydro, solar, and wind energy. Gibson et al. (2017) consider wind power the greenest one in a comparison between them because it is most likely the safest form of renewable energy concerning its overall ecological impacts. lslam et al. (2013) say that it is an energy source economically efficient and affordable for widespread use in the future. They list some advantages of wind energy: (a) it has technological maturity, good infrastructure, and its cost is relatively competitive when 
compared to other renewable energy sources, (b) in locations with quality wind resources, it presents itself as a good option concerning traditional technologies for fossil fuel generation, and (c) it is available through the world, thereby reducing dependence on energy imports between countries. Agalar \& Kaplan (2018) reinforce this position claiming that wind energy is one of the most competitive sources of renewable energy when technical, geographic, and social issues are considered. The Global Wind Energy Council (GWEC) considers it, regarding the environmental impact, as the potential future "backbone of energy systems in many parts of the world" (Global Wind Energy Council, 2021, p. 2).

Zhou et al. (2012) point out that some uncertainties are settled, such as the cost of wind power and the amount of wind that can be effectively incorporated into the electricity grids. Recent studies have reported that "[...] the costs of wind power have declined to levels on par with or below those of conventional sources in many parts of the world" (Beiter et al., 2021, p. e398, and, nowadays, it is one of the renewable energy sources most widely used around the world (Sadorsky, 2021).

Innovations in design, materials, processes, and logistics allowed weightier turbines to develop at lower costs, contributing to the spread of their use. The literature also cites other subjects as better land exploitation, reduction of maintenance and operation requirements, and technology issues as grid integration (Kaldellis \& Zafirakis, 2011). The turbines' technological advances, mainly from the 1980s, have increased energy production and reduced weight and noise. Therefore, these aspects make wind power increasingly more attractive regarding economic and environmental factors (1slam et al., 2013).

Many of these innovations resulted from increased investment and attractive policies to stimulate installed capacity expansion and the use of wind energy in several countries (Chang et al., 2021; Hille et al., 2020; Sahu, 2018). Effectively, the generation and use of wind power have rapidly expanded (International Renewable Energy Agency, 2021). In 2020, the global installed capacity of wind power reached $743 \mathrm{GW}$, a growth of 14\% compared to 2019. The expectation for the coming years is to exceed 1TW before 2025 (Global Wind Energy Council, 2021).

During the 1980s and 1990s decades, the wind power industry was dominated by the United States and by European countries, especially Denmark, Germany, France, and the United Kingdom. In the 2000s, other players have emerged, such as China, India, Korea, and Taiwan. This market, however, presents several barriers to the entry of new competitors. It is dominated by few companies with considerable experience in turbine manufacturing, highly specialized technology, and high initial investments (Lewis, 2011; Kim et al., 2014). A common strategy to enter this market - usually adopted by emerging countries - is through technology transfer involving mechanisms such as Foreign Direct lnvestment, Overseas Development Aid, foreign-acquired technologies, mergers and acquisitions, patent licensing, joint ventures, and other agreements and partnerships (Lewis, 2011; Urban et al. 2015; Nordensvard et al., 2018).

Because of the sector's characteristics and dynamics, patent protection has become an increasingly important factor for companies to improve their economic value in the wind power industry (Kim et al., 2018). The number of patent deposits related to wind energy has increased, reflecting intellectual property rights concerns.

Patent documents are a well-known innovation indicator (Organisation for Economic Co-operation and Development, 2009) and have a set of available and easily accessible information (Hunt et al., 2007). Thus, several studies related to wind energy have been conducted based on patent data, and most of them have focused on the following approaches:

- Evaluation of the effects of renewable energy policies and other actions using patents as an output indicator (Dubaric et al., 2011; Lindman \& Söderholm, 2016; Schleich et al., 2017; Miyamoto \& Takeuchi, 2019; Hille et al., 2020);

- Monitoring and identification of wind power's trends and technological solutions from patent documents (Lee \& Lee, 2013; Tsai et al., 2016; Madvar et al., 2019; Baca et al., 2020);

- Development of new analysis methodologies using patents documents on wind and other renewable energy as application examples (Daim et al., 2012; De Rassenfosse et al., 2013; Altuntas \& Gök, 2020).

Other wind energy studies related to technology transfer or knowledge transfer have also used patent documents as an indicator to substantiate theories or to analyze specific cases of selected countries. Nordensvard et al. (2018), for instance, used citation network analysis and patent analysis to compare knowledge flows between wind firms to understand the process of innovation catch up and how an emerging economy can have sectors that could be defined as innovation core and source for technology transfer. Urban et al. (2015) explored the role technology transfer/cooperation from Europe played in shaping firm-level wind energy technologies in China and India. Lema \& Lema (2013) used the case of wind power Clean Development Mechanism (CDM) 
to analyze how technology transfer occurs, identifying a diversity of transfer mechanisms based on China and India's experience. Haščič \& Johnstone (2011) examined the effect of the Kyoto Protocol's CDM on the international transfer of wind power technologies using patent data from over 100 countries during 1988-2008. In turn, Kim et al. (2018) conducted research focused on patent protection on firms' market value, analyzing the renewable energy sector case. As a result, the authors suggest that patent protection ability is a relevant factor for companies improving their financial performance.

From a country's perspective, a patent portfolio in a given area reveals its technological domain or dependence when comparing national and foreign applicants and types of patent applications (Yuan et al., 2015). These studies corroborate that patent analysis effectively presents the paths taken by technology from its inception to its market maturity.

In the past, wind energy was used as mechanical energy mainly to propel ships, to drive windmills to grind grain, and to pump water ( $\mathrm{Xu} \& \mathrm{Li}, 2016)$. Currently, the wind turbine converts the wind's kinetic energy into electrical energy. Modern wind turbines work with aerodynamic lift forces. A wind turbine typically consists of blades, a rotor, a tower, a gearbox, a generator, a controller, anemometer, a heat exchanger, and a wind vane (Kumar et al., 2016). Wind turbine technology significantly improved generated power output and efficiency, reducing generation costs due to increased capacity factors such as more prominent towers with larger blades (Kumar et al., 2016; Agalar \& Kaplan, 2018; Sadorsky, 2021).

In addition to developments in wind turbines, the literature describes advances in digital technologies that reduce maintenance and management costs in wind generation. Chang et al. (2021) describe a new software to reduce development time and costs by facilitating wind turbines' modular engineering design. The authors also mention a new camera system supported by artificial intelligence, which aims at combating bird accidents, protecting both birds and blades simultaneously.

Technological systems for wind generation are advancing to solve integration problems with the existing grid, where new power conditioning and voltage mitigation devices are being developed to quickly respond to power grid disturbances (Agalar \& Kaplan, 2018). A more detailed view of the technological evolution of different onshore or offshore wind systems components can be seen in Watson et al. (2019). The authors present a review of future emerging technologies in the wind energy sector, considering their potential, challenges, applications, technology readiness, and how they might evolve in the coming years.

The main barrier to further adoption of wind energy is still the cost of installation and maintenance (Kumar et al., 2016; Chang et al., 2021). However, it is essential to emphasize that even though it is noticeable that wind energy technologies have followed a cost-cutting path over time (Elia et al., 2021; Beiter et al., 2021), governments still play a crucial role in the full adoption of wind energy, through legislation, regulations, and long-term development plans.

In line with the importance of wind energy in the current scenario, this study presents the results of a technological analysis on wind energy based on patent documents classified with code F03D - "Wind Motors." Nonetheless, the study based on wind energy patents presented in this article has a special approach. It is focused on the major countries and companies that develop wind turbines and aims to answer the following questions:

(i) Is there a relationship between the leading developers of wind turbines and the main manufacturers of this technology?

(ii) Is there a pattern of technological development among the companies that develop this type of technology?

(iii) What is the flow of technology transfer between the main countries that develop this technology?

In addition to presenting updated data, this article brings new indicators related to technology transfer and patenting patterns that have not been explored yet. As pointed out in the literature (Kim et al., 2018; Lee \& Lee, 2013), there is a need for further investigation on patent protection in this sector. Urban et al. (2015) also highlight that the role of firms for technology transfer in the wind industry has not received enough attention in the literature. Then, the results of this study can provide more information to support future research and analyses on this issue.

This study is structured as follows: in Section 1, a summarized literature review highlights the importance of the input chosen for the study - patents - while emphasizing technological patterns and also brings market information on wind energy with the importance of the theme, goal, and gaps that justify the development of the research. The methodology used is presented in Section 2, and Section 3 shows the results obtained. Finally, Section 4 shows the final considerations reached from the study and presents suggestions for future research on the theme. 


\section{Method}

This study was based on data from patent documents on wind energy filed in the principal patent offices of the world, retrieved from Derwent ${ }^{\circledR}$ Innovation Index (Clarivate Analytics).

The search strategy used was based on the code F03D* ("Wind Motors") of the International Patent Classification (IPC). This code is part of the IPC Green Inventory developed by the World Intellectual Property Organization (WIPO) to facilitate the search for patent information related to Environmentally Sound Technologies (ESTs), according to the United Nations Framework Convention on Climate Change (UNFCCC). The survey covered all patent documents with publication dates until the end of 2016. This time limit was established because the patent applications are confidential for 18 months.

The survey retrieval 55,223 records, each one corresponding to a patent family. A patent family can be defined as a set of all equivalent patent documents corresponding to a single invention, filed at the various patent offices worldwide to seek protection in different geographical regions (Organisation for Economic Co-operation and Development, 2011).

The leading technology developers were identified at two levels: macro-level (countries); and micro-level (institutions/companies). At the macro-level, the countries of technology origins were mapped from the priority number of patent documents indicating the first filing country (De Marco et al., 2017).

The countries with the largest number of patents deposited on wind motors were also identified at the macrolevel. As patent protection follows the principle of territoriality established by the Paris Union Convention, the rights conferred by a patent are valid only in the regions/countries in which it was deposited and granted. Thus, many deposits made by residents and foreigners indicate that the country is a potential market for exploiting that technology.

At the micro-level (institutions/companies), the leading developers of this technology were identified from patent assignees, the entities (individuals or corporates) with the property right to the patent. The name of the institutions (companies) was normalized using the OpenRefine ${ }^{\circledR}$ software.

Correlation Networks are based on pairwise correlations between variables. Zhang \& Horvath (2005) used it to obtain insight into cellular processes. It is the underpinning for data mining methods used to study genetic data (Friedman \& Alm, 2012), but it is also applied for patent studies. Choi \& Hwang (2014) used correlation networks to analyze led technologies. Long \& Ma (2016) used centrality measures to identify the core technologies in the metro domain of patents, using field domains. Liu et al. (2021) used correlation networks for studying spillovers of green technologies in China.

The identification of the similarities between the patents technological focus deposited by the companies was based on the IPC codes and covered the following steps:

(i) Identification of IPC codes: each patent document can contain several IPC codes. All codes related to at least one patent document analyzed in this study were identified in this first stage. In total, 147 different IPC codes were identified;

(ii) Definition of vectors: for each company (assignee), a vector was created with the indication of the number of patents deposited in each IPC code identified in step (i);

(iii) Matrix construction: a matrix was built (according to Figure 1) to verify the similarity of the technologies developed by the companies. In this matrix, the columns indicated the IPC codes of step (i), and the lines represented the vectors of each company (assignee) defined in step (ii);

\begin{tabular}{|c|c|c|c|c|c|c|}
\cline { 2 - 7 } \multicolumn{1}{c|}{} & \multicolumn{7}{c|}{ 147 IPC codes } \\
\cline { 2 - 7 } \multicolumn{1}{c|}{} & Code 1 & Code 2 & Code 3 & $\ldots$ & $\ldots$ & Code 147 \\
\hline Company 1 & $\mathrm{x}$ & & $\mathrm{x}$ & & $\ldots$ & \\
\hline Company 2 & $\mathrm{x}$ & $\mathrm{x}$ & $\mathrm{x}$ & $\mathrm{x}$ & & $\mathrm{x}$ \\
\hline Company 3 & & $\mathrm{x}$ & $\mathrm{x}$ & $\mathrm{x}$ & $\ldots$ & \\
\hline$\ldots$ & $\mathrm{x}$ & & & & $\ldots$ & $\ldots$ \\
\hline Company n & & $\mathrm{x}$ & $\mathrm{x}$ & $\mathrm{x}$ & & $\mathrm{x}$ \\
\hline
\end{tabular}

$x=$ Number of patent documents classified in each IPC code.

Figure 1. Representation of the IPC code matrix of the patents on wind energy filed by the companies. 
(iv) Network construction: from the matrix in step (iii), a correlation network was built between the fifty biggest assignees based on the similarity of the focus of the filed patents or countries. In this network, each node represented a company or a country, and the edges represented the relationship of deposit similarity between the companies. Similarity relationships (correlations) below 0.8 were excluded, allowing clusters identification of companies with similar patent filing patterns. For the construction and representation of citation networks, it was used the Pajek ${ }^{\circledR}$ software, which is specific for studies of social network analysis.

Technology transfer was based on the patent family, based on patent filings made in other countries. Derwent database links these patents, indexing all documents from various international patent authorities into a patent family structure. Then, it was possible to identify the relation: FROM (country of origin of the technology, considering the priority number) TO (countries where the patent was filed).

A network was created in which the vertices are represented by the countries in which the priorities are filed, and the arcs represent the patents filed from the original priorities. The values of the arcs of a country $i$ in a country $\mathrm{j}$ represent the total deposits starting from the priorities in a country $i$ that generated deposits in country j. It is important to note that patenting in other countries has been used as a measure of technology transfer (De Rassenfosse et al., 2013; Johnstone et al., 2011), and the family size can be considered as an indicator of the geographical breadth for which protection of the invention is sought (Organisation for Economic Co-operation and Development, 2011).

Finally, other studies and reports related to wind power were also consulted to support the results obtained from the patent analysis.

\section{Results}

\subsection{Relationships between main developers of wind turbines and manufactures}

Regarding the main wind turbines developer countries, the survey pointed out China, United States, Germany, South Korea, and Japan as the leading countries developing wind motors technologies. These five countries concentrate more than $70 \%$ of the patents deposited at the leading patent offices, considering the priority number (criteria adopted as the origin of the technology in this study). Russia, Taiwan, United Kingdom, Denmark, and France complete the list of the top ten countries considered developers of this technology, as shown in Table 1.

According to data from International Renewable Energy Agency (2021), the ten countries with the largest accumulated capacity of wind energy are China, the USA, Germany, India, Spain, UK, France, Brazil, Canada, and ltaly. Therefore, five countries are on the list of main technology developers and have the largest installed capacity. China, the USA, and Germany occupy the top three positions in both rankings. These three countries are responsible for 56\% of the patents deposited considering the priority number and 63\% of wind power installed capacity in the world.

Table 1. Top 10 wind turbines developer countries considering the number of patents filed and the wind power and renewable energy installed capacities.

\begin{tabular}{|c|c|c|c|c|c|c|c|c|}
\hline \multicolumn{3}{|c|}{$\begin{array}{c}\text { Patent Filed } \\
\text { (Priority Country) }\end{array}$} & \multicolumn{3}{|c|}{$\begin{array}{l}\text { Wind Power* } \\
\text { (Installed capacity - 2020) }\end{array}$} & \multicolumn{3}{|c|}{$\begin{array}{c}\text { Renewable Energy* } \\
\text { (Installed capacity - 2020) }\end{array}$} \\
\hline Country & Number & $\%$ & Total & $\%$ (world) & $\begin{array}{c}\% R E \\
\text { (country) }\end{array}$ & Total & $\%$ (world) & $\begin{array}{c}\% E C \\
\text { (country) }\end{array}$ \\
\hline China & 19,783 & 35.8 & 281,993 & 38.5 & 31.5 & 894,879 & 32.0 & 40.6 \\
\hline USA & 5,742 & 10.4 & 117,744 & 16.1 & 40.3 & 292,065 & 10.4 & 25.4 \\
\hline German & 5,490 & 9.9 & 62,184 & 8.5 & 47.2 & 131,739 & 4.7 & 56.3 \\
\hline S. Korea & 4,572 & 8.3 & 1,636 & 0.2 & 8.4 & 19,589 & 0.7 & 14.3 \\
\hline Japan & 4,547 & 8.2 & 4,206 & 0.6 & 4.2 & 101,370 & 3.6 & 29.3 \\
\hline Russia & 1,762 & 3.2 & 945 & 0.1 & 1.7 & 54,274 & 1.9 & 19.8 \\
\hline Taiwan & 1,164 & 2.1 & 854 & 0.1 & 9.3 & 9,158 & 0.3 & 15.9 \\
\hline UK & 1,149 & 2.1 & 24,665 & 3.4 & 51.7 & 47,676 & 1.7 & 45.2 \\
\hline Denmark & 1,097 & 2.0 & 6,235 & 0.9 & 64.4 & 9,677 & 0.4 & 62.0 \\
\hline France & 1,067 & 1.9 & 17,382 & 2.4 & 31.4 & 55,365 & 2.0 & 40.5 \\
\hline Top 10 & 46,373 & 84.0 & 517,844 & 70.6 & & $1,615,792$ & 57.7 & \\
\hline Total World & 55,223 & 100.0 & 733,276 & 100.0 & & $2,799,094$ & 100.0 & \\
\hline
\end{tabular}

Note: RE is Renewable Energy, and EC is Electricity Capacity. *International Renewable Energy Agency (2021). 
The ten countries listed in Table 1 concentrate $84 \%$ of the patents analyzed in this study, $70.6 \%$ of the installed wind power capacity, and 57.7\% of the planet's renewable energy. However, as can be seen, the share of wind energy in the installed capacity of renewable energy varies widely between the countries. The same happens with the participation of renewable energies in the electricity generation capacity.

In the case of China, the growth in the number of patent applications occurred mainly in recent years. It must be considered that China has invested heavily in the development and use of renewable energy, also encouraging the domestic production of wind turbines (Klagge et al., 2012; Sahu, 2018; Liu et al., 2021). The development of wind power in this country has intensified since 2003, especially after the 2005 Renewable Energy Law and the 11th Five-Year-Plan (2006-2010) period, which led to the establishment of a set of policies and financial incentives facing the industry (Hu \& Cheng, 2013; Dai et al., 2018). R\&D efforts from universities and research institutions, import of equipment and technical support (especially in the first stage, until the mid-90s), foreign technology transfer (licensing, foreign direct investment, and joint design activities), cross-border technological learning, and the utilization of know-how from related industries (such as electric power generation equipment or heavy machinery and equipment) greatly contributed to the development of the wind industry in China (Klagge et al., 2012; Liu et al., 2021). From importer of wind power equipment, China has quickly taken a leading position in this industry, with Chinese companies expanding their business overseas (Feng et al., 2015). As pointed out by Klagge et al. (2012), "China, the world's biggest producer of carbon dioxide, also became the world's largest wind energy market."

In the United States occurred an increase in the number of patents filed in the 1970s, probably due to the search for alternative energy after the petroleum crisis. In the 1980s, however, there was a decline in patenting related to wind energy. According to Nemet \& Kammen (2007), this decline also occurred in other energy sources, such as photovoltaic and nuclear fusion. It was accompanied by a reduction in public and private investments in R\&D in the energy sector in that period. In turn, since the early 1990s, various federal and state policies have been established to promote wind energy production and use in the country (Crowe, 2020; Platzer, 2012). These support policies probably contributed to the resumption of growth in patenting in the 2000s. The government incentives, the market forces, and the reduction in wind energy production costs have also stimulated the growth of this energy source in the country. The installed capacity also has increased every year (Global Wind Energy Council, 2021).

Germany, in turn, also has encouraged the use of wind energy since the 1970s (Klaassen et al., 2005). It was one of the first countries to introduce targets for wind power development through the ' 100 MW Program' announced in 1989. In 1991, the German government promoted an upgrade of this renewable portfolio standard to the "250 MW Program" and other initiatives to stimulate and support the development of wind power development (Valentine, 2015). Since establishing an official target suggests the importance of a subject, the expansion of R\&D efforts and patenting activities is expected (Schleich et al., 2017). In Germany's case, wind power patenting increased significantly from the late 1990s and onwards (Lindman \& Söderholm, 2016). Together with Denmark and California (United States), this country is considered a pioneer of the modern wind industry (Klagge et al., 2012). These three countries have high patenting in wind-power technologies and play an important role in innovation in this field (Schleich et al., 2017). Currently, Germany occupies the third position in the international ranking with $62 \mathrm{GW}$ of installed capacity, representing around 8.5\% of the world's capacity (Global Wind Energy Council, 2021).

South Korea, Japan, Russia, Taiwan, and Denmark are among the main developers of wind power technology, but these countries do not stand out in the top ten installed capacity in 2020 and 2015. Considering the other countries listed in the ranking of leading developers of wind turbine technology, only the United Kingdom and France are also ranked among the ten countries with the largest cumulative capacity of wind power, but with a smaller share compared to China, United States, and Germany.

South Korea is the fourth country with higher priority number in patents deposited on wind motors. The first wind farm was constructed only in 1997 as a pilot project of the Korean government. The country has invested in R\&D in order to develop advanced technologies and facilitate the commercialization of renewable energy technology. Considering the several sources of renewable energy, wind power has attracted increasing attention in Korea for two factors: it is the most technically advanced and economical source of renewable energy, and numerous places in Korea experience heavy winds on a year-round basis (Kim et al., 2014). Lewis (2011) says that "South Korea is still a relative newcomer to the wind industry, but the recent entry of many large Korean industrial firms makes it well-positioned for future growth." Despite this expectation, the increase of wind power installations in Korea has presented slow growth (Global Wind Energy Council, 2018).

Japan is the fifth country with higher priority number in patent documents on wind motors. Although the start of wind power generation began in 1980, its growth was from the late 1990s. The Fukushima Nuclear Plant 
Accident and subsequent shutdowns of reactors elsewhere in Japan widened the debate about the importance of investing in other energy sources (Mizuno, 2014). However, wind development in Japan has been slow due to unclear and inconsistent policies related to this renewable energy (Valentine, 2011; Global Wind Energy Council, 2018).

Russia started early the development of technologies in this field. In 1930, the old USSR produced smallscale wind turbines, but this action was abandoned later when started the era of large power stations. Over the years, Russia has favored other sources of energy based on fossil fuels, nuclear, and hydropower facilities. Only recently (after the 2010s), the country has established policies to stimulate the development of renewable energies, but the use of this type of energy is still negligible (Lanshina et al., 2018; Ermolenko et al., 2017).

Among renewable energies, Taiwan has emphasized the development of wind and photovoltaic power. However, this kind of energy development is still in the initial stage (Liou, 2015). R\&D efforts related to wind power started only in 1980. Twenty years after, the government launched a project to promote wind power generations. Another initiative in this direction was the technical support for domestic companies through specific research institutions.

In Denmark, the development of wind power was different when compared to larger industrial countries. It was based on small private innovators, small farm equipment industries, and communities in cooperative structures (Hvelplund et al., 2021; Mey \& Diesendorf, 2018). Denmark started installations several years before other European countries and held the lead with the highest cumulative installed wind power capacity until 1993, when it was surpassed by Germany (Grafström \& Lindman, 2017). The country has always stood out as one of the main developers of wind power technologies, having tradition and a long history in this field (Curran et al., 2017).

On the other hand, at the micro-level (main wind turbines developer companies), General Electric, Vestas, and Siemens stand out as developers of wind motors technologies with more than a thousand patents each. Mitsubishi, Samsung, Goldwind, Guodian, Enercon, Senvion, Hitachi, Nordex, Sinovel, Gamesa, Alstom, and Mingyang complete the list of companies with more than 200 patents deposited (Table 2).

Table 2. Main wind motors developers, considering assignees of patent deposited worldwide.

\begin{tabular}{cc}
\hline Quantity of patents deposited & Companies \\
\hline More than 1,000 & General Electric (USA) \\
& Vestas (Denmark) \\
More than 500 & Siemens (Germany) \\
& Mitsubishi (Japan) \\
More than 400 & Samsung (South Korea) \\
More than 300 & Goldwind (China) \\
& Guodian (China) \\
& Enercon/Wobben (Germany) \\
More than 200 & Senvion/Repower (Germany) \\
& Hitachi (Japan) \\
& Nordex (Germany) \\
& Sinovel (China) \\
& Gamesa (Spain) \\
& Alstom (Spain) \\
& Mingyang (China) \\
\hline
\end{tabular}

Table 3 shows the Bloomberg ranking of the top 10 wind turbine manufacturers in 2020. It is formed by GE, Goldwin, Vestas, Envision, Siemens-Gamesa, Mingyang, Shangai Electric, Windey, CCRC, and Sany. Table 4 complements the list, including the names of other companies that integrated this ranking in the last five years.

According to Tables 3 and 4, among the fifteen companies, ten are Chinese, which shows China's penetration in this field of renewable energy. However, it is observed that Chinese companies have a very restricted performance in the APAC market. Even Chinese companies Goldwind and Envision have a predominant presence in their domestic market. In turn, companies in Europe and the USA have a broader and more diversified market (EMEA, AMER, and APAC) with penetration in several countries and continents. 
Table 3. Top 10 global wind turbine manufacturers (2020).

\begin{tabular}{|c|c|c|c|c|c|c|}
\hline Company & $\begin{array}{c}\text { Total } \\
\text { Commissioned } \\
\text { capacity GW }\end{array}$ & $\begin{array}{c}\text { Onshore } \\
\text { Commissioned } \\
\text { capacity GW }\end{array}$ & $\begin{array}{c}\text { Offshore } \\
\text { Commissioned } \\
\text { capacity GW }\end{array}$ & Country of origin & $\begin{array}{l}\text { Markets supplied } \\
\text { in } 2020\end{array}$ & $\begin{array}{c}\text { Year of } \\
\text { foundation or } \\
\text { wind power } \\
\text { operations }\end{array}$ \\
\hline $\mathrm{GE}$ & 13.53 & 13.53 & 0 & USA & $\begin{array}{l}\text { AMER, EMEA, } \\
\text { APAC }\end{array}$ & 2002 \\
\hline Goldwind & 13.06 & 12.75 & 0.31 & China & $\begin{array}{c}\text { APAC, AMER, } \\
\text { EMEA }\end{array}$ & 1998 \\
\hline Vestas & 12.40 & 12.16 & 0.24 & Denmark & $\begin{array}{c}\text { EMEA, AMER, } \\
\text { APAC }\end{array}$ & 1986 \\
\hline Envision & 10.35 & 9.48 & 0.87 & China & APAC, AMER & 2007 \\
\hline Siemens Gamesa & 7.65 & 5.74 & 1.91 & $\begin{array}{l}\text { Germany and } \\
\text { Spain }\end{array}$ & $\begin{array}{c}\text { EMEA, AMER, } \\
\text { APAC }\end{array}$ & $\begin{array}{l}2004 \text { (Siemens) } \\
1994 \text { (Gamesa) }\end{array}$ \\
\hline Mingyang & 5.64 & 4.76 & 0.88 & China & APAC & 2006 \\
\hline Shangai Electric & 5.07 & 3.98 & 1.09 & China & APAC & 2004 \\
\hline Windey & 3.98 & 3.84 & 0.14 & China & APAC & 2001 \\
\hline CRRC & 3.84 & 3.72 & 0.12 & China & APAC & 2010 \\
\hline Sany & 3.72 & 3.52 & 0.20 & China & APAC & 2010 \\
\hline
\end{tabular}

Note: APAC is the Asia Pacific; EMEA is Europe, Middle East, and Africa; and AMER is North, Central, and South America. Source: BloombergNEF (BNEF, 2021) and companies' websites.

Table 4. Other main wind turbine manufacturers in the last years.

\begin{tabular}{ccccc}
\hline Company & Country of origin & $\begin{array}{c}\text { Markets supplied when } \\
\text { listed in the ranking }\end{array}$ & $\begin{array}{c}\text { Year (foundation or wind } \\
\text { power operations) }\end{array}$ & Ranking (year)* \\
\hline Enercon & Germany & EMEA, AMER, APAC & 1984 & 2019 \\
Guodian UP & China & APAC & 2007 & 2018 \\
CSIC (CSSC) & China & APAC & 2004 & 2015 \\
Nordex & Denmark & EMEA, AMER & 1985 & 2019 \\
Dongfang & China & APAC & 1984 & 2019 \\
\hline
\end{tabular}

*Bloomberg's ranking was based on onshore and offshore in 2020 and 2019. Only onshore was considered in other years. Source: BloombergNEF and companies' websites.

The three companies with the highest number of patents filed on wind motors (GE, Vestas, and Siemens) are also listed among the highest total commissioned capacity (GW). General Electric entered the wind power market in 2002 when it acquired Enron Wind Corp. Vestas began to concentrate exclusively on wind energy in 1986, founding the new Vestas Wind Systems A/S. In 2004, the company merged with another Danish wind turbine manufacturer, NEG Micon A/S. Siemens entered the global market for wind power in 2004 with the acquisition of Bonus Energy, a Danish company created in 1980. The Bonus Energy was one of the world's five largest suppliers of wind energy systems. In 2017, Siemens merged with Gamesa. This Spanish company, established in 1976, began working with wind turbines in 1994. In 2002, Gamesa acquired Echesa (gearboxes), Cantarey (generators), Enertrón (converters), Made, and Navitas. Although Siemens and Gamesa merged their wind power businesses, the two companies have always been among the leading technology developers and turbine manufacturers.

Goldwind, Guodian, Enercon, Nordex, and Mingyang are also listed among the largest patent applicants and the largest wind turbine manufacturers. Enercon was created in 1984 by Aloys Wobben and is the largest German wind turbine company. Nordex was created in 1985 in Denmark and merged with the Spanish Acciona Windpower in 2016. Goldwind is a Chinese state-owned company founded in 1998, while Guodian and Mingyang, also Chinese, date from 2007 and 2006.

Mitsubishi and Samsung, despite more than 500 patents filed, do not appear in the ranking of Tables 3 and 4. Mitsubishi, meanwhile, formed a joint venture with Vestas in 2014, creating MHI Vestas Offshore Wind. The wind capacity of MHI Vestas is not attributed to Vestas in the Bloomberg ranking. Even counting separately, $\mathrm{MHI}$ Vestas would have occupied the tenth position of this ranking if they were considered onshore and offshore wind capacity. In turn, through the subsidiary Samsung Renewable Energy lnc. (SRE), Samsung has been developing wind energy projects in Canada.

Hitachi, Sinovel, Senvion, and Alstom, with more than two hundred patent filings, are also among the most prominent developers of wind turbine technology, considering the number of patent filings. These four companies also do not appear as the leading wind turbine manufacturers. However, Sinovel was listed in the Top 10 Wind 
Turbine Manufacturers elaborated by Energy Acuity (2019), using another methodology based on 143 wind manufacturer project pipelines, innovations, and strategic initiatives. In the case of Alstom, the company was acquired by General Electric in 2015 to reinforce its performance in wind energy. The Japanese Hitachi has been working in partnership with the German Enercon. In turn, Senvion, formerly called REpower, started in 2001 with the merger of 3 companies. In 2012, the Indian company Suzlon started to hold 100\% of its capital.

Envision, Shanghai, Windey, CRRC, Sany, CSIC, Dongfang, companies listed among the largest wind turbine manufacturers, have also filed patent applications. Despite the smaller quantity (less than 200 deposits), all these companies have several patents with the code F03D, which indicates that they have also been investing in developing technologies related to wind turbines.

Therefore, this data shows that significant technology developers are also essential players in the wind turbine market. They also reveal the concern of these companies to protect their inventions through intellectual property rights, reinforcing what was pointed out by Kim et al. (2018) concerning the wind industry.

\subsection{Technological patterns}

To check if there is a pattern of technological development among companies, two networks were created based on the pairwise correlations between the vectors and the number of patents in each domain of the classification.

Countries were used in the first network as vertices. The top fifty assignees formed the second network. From the correlation matrix between the vectors, correlation networks were set up. For each assignee, a vector was created with the number of patents deposited in each IPC code in each vector entry.

Considering Figure 2, a network is presented in which the vertices are the countries, and the edges are established by the correlations of the vectors related to the deposits in the different classifications of the IPC. For the network with $\rho>0.8$, China (CN) appears connected to eight countries (AU-0.89, TW-0.88, JP-0.87, US-0.84, CA-0.83, KR-0.83, DE-0.81, SE-0.81). When $\rho>0.85$, the country appears linked to three others (AU, TW, JP). With $\rho>0.9$, the country is not connected to any other country.

Figure 2 indicates that there may be a differentiation in the deposit pattern of China relative to other countries. However, since a non-Chinese company can deposit as a priority in China, one should check the assignee's network. One can see how this occurs by checking the top depositor's network. In the second network, the vertices are the companies that have filed the most patents.
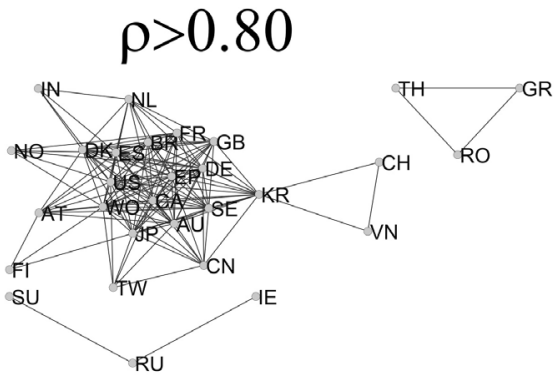

$\rho>0.90$

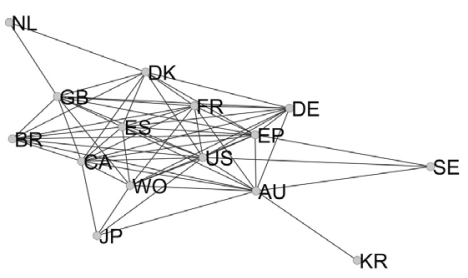

$\mathrm{CN}$
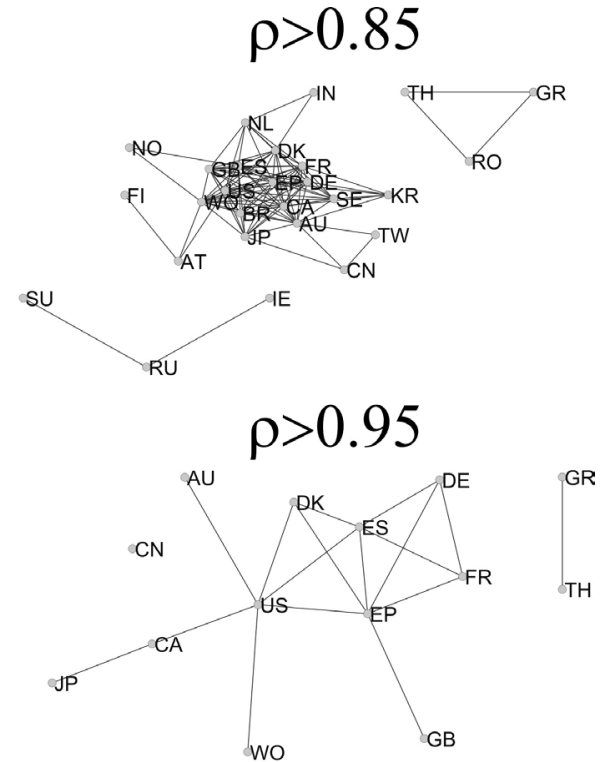

Figure 2. Clusters in the country network. When $\rho>0.8$, China is integrated into a larger component. When $\rho>0.90$, China (CN) separates from the network, indicating a difference in deposit patterns. Country codes can be found at World Intellectual

Property Organization (2021). 
The vertices of the second network are the patent assignees, and the edges are the correlations of the vectors produced for each of the 50 largest applicants. In the correlation network between company assignees, groups of companies start to be marked with $\rho>0.85$. With $\rho>0.90$, the separate clusters are joined only by two connections, while they separate into two components when $\rho>0.95$ (Figure 3).

Each cluster represents a set of companies with a similar patent filing pattern. Considering that the correlation occurs between vectors formed by the number of patents filed in each item of the IPC, two linked companies with an edge with high correlation will have similar depositing patterns. In Figure 3, the names of the companies of the clusters appear. It appears that the Chinese biggest assignees are concentrated in one of the clusters, along with some Korean companies, with GE and European companies in the second cluster.

\section{$\rho=0.95$}
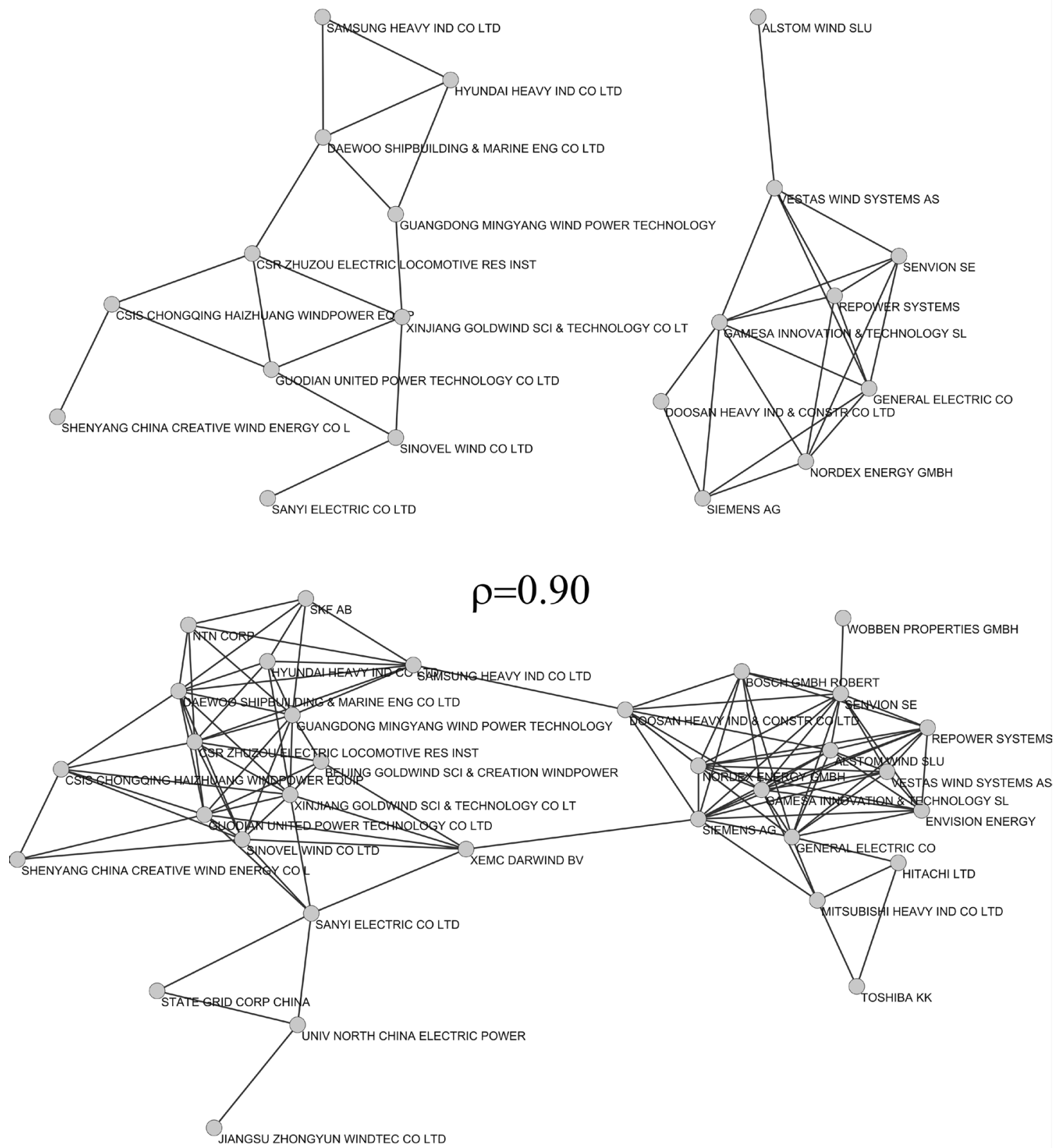

Figure 3. Clusters of companies with $\rho>0.9$ and $\rho>0.95$. Chinese companies are grouped into one component. 
Considering the cluster where the Chinese companies are inserted, there is a higher deposits concentration among the large depositors in more scattered classes: (F03D-011/00 - Details, component parts, or accessories) and wind motor controls (F03D-007/00). It is possible to observe a lower preponderance of the F03D-011/00 class (18.364\% vs. $31.797 \%$ of deposits) in the other cluster, in which there is a higher filings percentage in patent groups related to wind engines (F03D-001/06, F03D-009/00, F03D-007/02, F03D-001/00, F03D-007/04, F03D-003/ $06-43,718 \%$ vs 56.081\% of deposits). Table 5 shows a percentage of each field on the deposits on the Companies Correlation Network.

Table 5. Percentage of each field on the deposits on Companies Correlation Network with $\rho>0.9$. Chinese companies are concentrated on Cluster 1.

\begin{tabular}{|c|c|c|c|c|c|}
\hline IPC & Description & Cluster 1 & Pos Cluster 1 & Cluster 2 & Pos Cluster 2 \\
\hline F03D-011/00 & $\begin{array}{l}\text { Details, component parts, or accessories not provided for in, or } \\
\text { of interest apart from, the preceding groups }\end{array}$ & 31.797 & 1 & 18.364 & 1 \\
\hline F03D-007/00 & Controlling wind motors & 12.845 & 2 & 6.689 & 7 \\
\hline F03D-001/06 & $\begin{array}{l}\text { Wind motors with rotation axis substantially in wind } \\
\text { direction - Rotors }\end{array}$ & 8.477 & 3 & 11.155 & 2 \\
\hline F03D-009/00 & Adaptations of wind motors for special use & 8.255 & 4 & 10.917 & 3 \\
\hline F03D-011/04 & Mounting structures & 7.996 & 5 & 5.950 & 8 \\
\hline F03D-007/02 & $\begin{array}{l}\text { Controlling the wind motors having rotation axis substantially } \\
\text { in wind direction }\end{array}$ & 4.701 & 6 & 10.272 & 4 \\
\hline F03D-001/00 & Wind motors with rotation axis substantially in wind direction & 4.220 & 7 & 7.052 & 6 \\
\hline F03D-011/02 & Transmission of power, e.g., using hollow exhausting blades & 4.053 & 8 & 3.213 & 9 \\
\hline F03D-007/04 & Wind motors - controlling automatically & 3.665 & 9 & 8.925 & 5 \\
\hline F03D-003/06 & $\begin{array}{l}\text { Wind motors with rotation axis substantially at right angles to } \\
\text { wind direction - Rotors }\end{array}$ & 1.555 & 10 & 1.071 & 13 \\
\hline
\end{tabular}

\subsection{Technological transfers}

Figure 4 shows the flow of technology transfer between the main countries with patent deposited on wind energy (F03D). Each vertex represents a country where priorities are registered. Each arc, from one country $i$ to another $j$, represents the total deposits generated from the priorities of $\mathrm{i}$ in $\mathrm{j}$. It is a network that serves to indicate technology transfers from one country to another. We represented the technology transfer flow between the leading countries with patents filed on wind energy through a network with connections between the countries the assignee's file priorities and the other deposits locations. The technology transfer network considers only arcs with more than 1,000 filings.
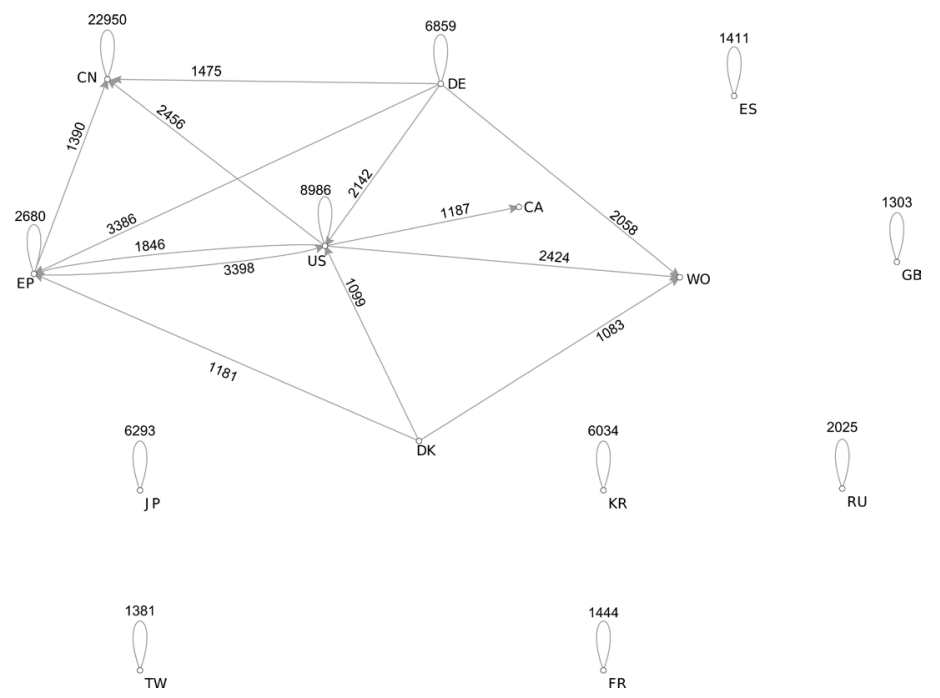

Figure 4. Technology transfer flow between the main countries with patent deposited on wind energy. The technology transfer network considers arcs with more than 1,000 deposits. 
Many countries seek to protect their technologies in the United States. Likewise, the United States deposits patents at several international offices. European countries also carry out technology transfer by filing patents in different markets. China, which is the country with the most significant number of patent filings (36\% of the world total, considering the country of priority), on the contrary, receives patent filings from several countries but performs very little technology transfer abroad.

This result is in line with the markets in which Chinese companies operate. As seen in Tables 3 and 4, many Chinese companies are restricted to APAC, unlike GE and other European companies that operate in different markets (APAC, AMER, and EMEA). This result may also reflect a relationship with the pattern of technologies developed by Chinese companies, which form a distinct cluster from GE and other large European companies based on the similarity of the IPC codes of the filed patents.

There are some aspects pointed out in the literature that help to understand these results better. China has established a solid policy to support renewable energies using stimulus mechanisms and substantial R\&D investments (Liu et al., 2021). According to data shown in this study, such initiatives made China take the lead in terms of installed capacity and the total number of patents deposited. However, this leadership happens when it comes to filing for local patents. When considering other markets, it is observed that China does not perform well compared to other countries with greater tradition in wind energy. This finding is reinforced by Hu et al. (2018). They say that China's wind industry lags behind other competitors such as Germany, Denmark, and the USA when compared performance indicators such as international patents, revenue, and exports.

Zhou et al. (2012) also point out that many patents of Chinese companies are of lesser value compared to patents outside companies. The explosive growth of patenting in China is also related to the implementation of patent subsidy programs in the various provincial regions of China when the number of deposits increased not only by companies, universities, and research institutes but also by individuals (Xibao, 2012). There are still some technical problems identified as weaknesses and hinder the performance of the wind energy industry in China (Grafström, 2019; Luo et al., 2016). Several Chinese companies are very young, and it is still necessary to promote more significant support for developing research related to wind energy to develop endogenous technologies. Other obstacles, such as legal uncertainty and weaknesses in intellectual property rights enforcement, supplement regulations that hamper international technology transfer (Klagge et al., 2012).

\section{Final considerations}

As noted in this study, the wind energy market is concentrated in a small number of companies, and it has a potential for expansion. Apart from the wind conditions, the technical viability of this type of energy is closely associated with the development of wind turbines. In this market, it can be observed that the most prominent players in the wind power global market made use of the strategy of acquiring and merging with other companies to expand their portfolio of business and gain market competitiveness.

GE and European companies have dominated the wind energy industry. However, in the last years, companies from emerging countries are also penetrating and becoming major players. Emphasis can be given to China. Several studies analyze this phenomenon in the literature since limited indigenous technical capacity and quality control of emerging economies are barriers to entry into this market. Therefore, companies' performance in these countries has been associated with technology transfer strategies, government incentives, and national policies aimed at renewable energy. This shows us how much government incentives are still important for the development of wind technologies. Although not focused on in the present study, we noted how direct government action is still necessary for adequate access to financial capital and adequate transmission infrastructure during the research.

This study indicates that these companies became important turbine manufacturers and started to invest in the development of new technologies and seek patent protection. However, companies from emerging countries, configured as new entrants, have a performance that is still restricted to a few markets compared to traditional companies such as GE and European companies. Likewise, it is observed that there is a pattern of technological development and a flow of technology transfer that also differentiates these two groups of companies.

Although there are some studies in the literature related to patents in the energy sector, this paper follows a different approach, presenting an overview that brings together technical and market information specific to wind energy. For future studies, a thorough analysis of technology holders is recommended considering different stages of technological development to show the variation in cost reduction at each stage of development and understand which dynamics are most significant in the diffusion of technological innovation related to wind energy. Finally, the authors hope that the findings of this study may bring contributions for researchers, students, professionals, and others interested in the technology and market of wind energy. 


\section{References}

Agalar, S., \& Kaplan, Y. A. (2018). Power quality improvement using STS and DVR in wind energy system. Renewable Energy, 118, 1031-1040.

Altuntas, F., \& Gök, M. S. (2020). Analysis of patent documents with utility mining: a case study of wind energy technology. Kybernetes, 50(9), 2548-2582. http://dx.doi.org/10.1108/K-06-2020-0365.

Baca, J. A. M., González, A. J. E., \& Montes, C. G. (2020). Analysis of the patent of a protective cover for Vertical-Axis Wind Turbines (VAWTs). Sustainability, 12, 7818.

Beiter, P., Cooperman, A., Lantz, E., Stehly, T., \& Shields, M. (2021). Wind power costs driven by innovation and experience with further reductions on the horizon. Wiley Interdisciplinary Reviews. Energy and Environment. http://dx.doi.org/10.1002/wene.398.

BloombergNEF - BNEF. (2021). Global Wind Industry Had a Record Near 100GW year as GE, Goldwind Took Lead From Vestas. From https://about.bnef.com/blog/global-wind-industry-had-a-record-near-100gw-year-as-ge-goldwind-took-lead-from-vestas/.

Chang, V., Chen, Y., Zhang, Z., Xu, Q. A., Baudier, P., \& Liu, B. S. C. (2021). The market challenge of wind turbine industry-renewable energy in PR China and Germany. Technological Forecasting and Social Change, 166, 120631.

Choi, J., \& Hwang, Y. (2014). Patent keyword network analysis for improving technology development efficiency. Technological Forecasting and Social Change, 83, 170-182.

Crowe, J. (2020). Explaining popular support for wind energy in the United States. Journal of Rural Social Sciences, $35(2), 2$.

Curran, L., Lv, P., \& Spigarelli, F. (2017). Chinese investment in the EU renewable energy sector: motives, synergies and policy implications. Energy Policy, 101, 670-682.

Dai, J., Yang, X., \& Wen, L. (2018). Development of wind power industry in China: a comprehensive assessment. Renewable and Sustainable Energy, 97, 156-164.

Daim, T., lskin, l., Li, X., Zielsdorff, C., Bayraktaroglu, A. E., Dereli, T., \& Durmusoglu, A. (2012). Patent analysis of wind energy technology using the patent alert system. World Patent Information, 34, 37-47.

De Marco, A., Scellato, G., Ughetto, E., \& Caviggioli, F. (2017). Global markets for technology: evidence from patent transactions. Research Policy, 46(9), 1644-1654.

De Rassenfosse, G., Dernisb, H., Guellecb, D., Picci, L., \& de la Potteriee, B. van P. (2013). The worldwide count of priority patents: a new indicator of inventive activity. Research Policy, 42, 720-737.

Dubaric, E., Giannoccaro, D., Bengtsson, R., \& Ackermann, T. (2011). Patent data as indicators of wind power technology development. World Patent Information, 33, 144-149.

Elia, A., Kamidelivand, M., Rogan, F., \& Gallachóir, B. 0. (2021). Impacts of innovation on renewable energy technology cost reductions. Renewable \& Sustainable Energy Reviews, 138. http://dx.doi.org/10.1016/j.rser.2020.110488.

Energy Acuity. (2019). Top 10 wind turbine manufacturers: wind supplier analysis. Retrieved in 2021, April 19, from https://www. energyacuity.com/blog/2019-top-10-wind-turbine-manufacturers/

Ermolenko, B. V., Ermolenko, G. V., Fetisova, Y. A., \& Proskuryakova, L. N. (2017). Wind and solar PV technical potentials: measurement methodology and assessments for Russia. Energy, 137, 1001-1012.

Feng, Y., Lin, H., Ho, S. L., Yan, J., Dong, J., Fang, S., \& Huang, Y. (2015). Overview of wind power generation in China: status and development. Renewable \& Sustainable Energy Reviews, 50, 847-858.

Friedman, J., \& Alm, E. J. (2012). Inferring correlation networks from genomic survey data. PLoS Computational Biology, 8(9), e1002687. PMid:23028285.

Gibson, L., Wilman, E. N., \& Laurance, W. F. (2017). How green is ‘green' energy? Trends in Ecology \& Evolution, 32(12), $922-935$. PMid:29074270.

Global Wind Energy Council - GWEC. (2018). Retrieved in 2018, January 15, from http://gwec.net/global-figures/wind-in-numbers/

Global Wind Energy Council - GWEC. (2021). Global Wind Report 2021. Retrieved in 2021, April 18, from https://gwec.net/globalwind-report-2021/

Grafström, J. (2019). Public policy failures related to China's wind power development (Working Paper, No. 320). Stockholm: RAT10.

Grafström, J., \& Lindman, A. (2017). Invention, innovation and diffusion in the European wind power sector. Technological Forecasting and Social Change, 114, 179-191.

Hao, F., \& Shao, W. (2021). What really drives the deployment of renewable energy? A global assessment of 118 countries. Energy Research \& Social Science, 72, 101880.

Haščič, 1., \& Johnstone, N. (2011). CDM and international technology transfer: empirical evidence on wind power. Climate Policy, 11, 1303-1314.

Hille, E., Althammer, W., \& Diederich, H. (2020). Environmental regulation and innovation in renewable energy technologies: Does the policy instrument matter? Technological Forecasting and Social Change, 153, 119921.

Hu, R., Skea, J., \& Hannon, M. J. (2018). Measuring the energy innovation process: an indicator framework and a case study of wind energy in China. Technological Forecasting and Social Change, 127, 227-244.

$\mathrm{Hu}$, Y., \& Cheng, H. (2013). Development and bottlenecks of renewable electricity generation in China: a critical review. Environmental Science \& Technology, 47(7), 3044-3056. PMid:23445126.

Hunt, D., Nguyen, L., \& Rodgers, M. (2007). Patent searching: tools \& techniques. New York: John Wiley \& Sons.

Hvelplund, F., Østergaard, P. A., \& Meyer, N. 1. (2021). Incentives and barriers for wind power expansion and system integration in Denmark. Energy Policy, 107, 573-584.

International Renewable Energy Agency - IRENA. (2021). Renewable capacity statistics 2021. Abu Dhabi: IRENA.

Islam, M. R., Mekhilef, S., \& Saidur, R. (2013). Progress and recent trends of wind energy technology. Renewable \& Sustainable Energy Reviews, 21, 456-468. 
Johnstone, N., Haščič, 1., \& Watson, F. (2011). Annex A: methodological issues in the development of indicators of innovation and transfer in environmental technologies. In Organisation for Economic Co-operation and Development - OECD (Ed.), Invention and transfer of environmental technologies (pp. 191-212). Paris: OECD Publications.

Kaldellis, J. K., \& Zafirakis, D. (2011). The wind energy (r)evolution: a short review of a long history. Renewable Energy, 36, $1887-1901$.

Kim, D., Kim, N., \& Kim, W. (2018). The effect of patent protection on firms' market value: the case of the renewable energy sector. Renewable \& Sustainable Energy Reviews, 82, 4309-4319.

Kim, K.-T., Lee, D.-J., \& Park, S.-J. (2014). Evaluation of R\&D investments in wind power in Korea using real option. Renewable \& Sustainable Energy Reviews, 40, 335-347.

Klaassen, G., Miketa, A., Larsen, K., \& Sundqvist, T. (2005). The impact of R\&D on innovation for wind energy in Denmark, Germany and the United Kingdom. Ecological Economics, 54, 227-240.

Klagge, B., Liu, Z., \& Silva, P. C. (2012). Constructing China's wind energy innovation system. Energy Policy, 50, $370-382$.

Kumar, Y., Ringenberg, J., Deperu, S. S., Devabhaktuni, V. K., Lee, J. W., Nikolaidis, E., Andersen, B., \& Afjeh, A. (2016). Wind energy: trends and enabling technologies. Renewable \& Sustainable Energy Reviews, 53, 209-224. http://dx.doi.org/10.1016/j.rser.2015.07.200.

Lanshina, T. A., Laitner, J. A. S., Potashnikov, V. Y., \& Barinova, V. A. (2018). The slow expansion of renewable energy in Russia: competitiveness and regulation issues. Energy Policy, 120, 600-609.

Lee, K., \& Lee, S. (2013). Patterns of technological innovation and evolution in the energy sector: a patent-based approach. Energy Policy, 59, 415-432.

Lema, A., \& Lema, R. (2013). Technology transfer in the clean development mechanism: Insights from wind power. Global Environmental Change, 23(1), 301-313.

Lewis, J. 1. (2011). Building a national wind turbine industry: experiences from China, India and South Korea. International Journal of Technology and Globalisation, 5, 281-305.

Lindman, A., \& Söderholm, P. (2016). Wind energy and green economy in Europe: measuring policy-induced innovation using patent data. Applied Energy, 179, 1351-1359.

Liou, H. M. (2015). Comparing feed-in tariff incentives in Taiwan and Germany. Renewable \& Sustainable Energy Reviews, 50, 1021 -1034.

Liu, Y., Shao, X., \& Tang, M. (2021). Spatio-temporal evolution of green innovation network and its multidimensional proximity analysis: Empirical evidence from China. Journal of Cleaner Production, 283, 124649.

Long, M., \& Ma, T. (2016). Weighted node importance contribution correlation matrix for identifying China's core metro technologies with patent network analysis. In F. Lehner \& N. Fteimi (Eds.), Proceedings of the KSEM 2016: Knowledge Science, Engineering and Management (pp. 199-208). Cham: Springer.

Luo, G. L., Li, Y. L., Tang, W. J., \& Wei, X. (2016). Wind curtailment of China’s wind power operation: evolution, causes and solutions. Renewable and Sustainable Energy, 53, 1190-1201.

Madvar, M. D., Ahmadi, F., Shirmohammadi, R., \& Aslani, A. (2019). Forecasting of wind energy technology domains based on the technology life cycle approach. Energy Reports, 5, 1236-1248.

Mey, F., \& Diesendorf, M. (2018). Who owns an energy transition? Strategic action fields and community wind energy in Denmark. Energy Research \& Social Science, 35, 108-117.

Miyamoto, M., \& Takeuchi, K. (2019). Climate agreement and technology diffusion: Impact of the Kyoto Protocol on international patent applications for renewable energy technologies. Energy Policy, 129, 1331-1338.

Mizuno, E. (2014). Overview of wind energy policy and development in Japan. Renewable \& Sustainable Energy Reviews, 40, 999-1018.

Nemet, G. F., \& Kammen, D. M. (2007). US Energy research and development: declining investment, increasing need, and the feasibility of expansion. Energy Policy, 35, 746-755.

Nordensvard, J., Zhou, Y., \& Zhang, X. (2018). Innovation core, innovation semi-periphery and technology transfer: The case of wind energy patents. Energy Policy, 120, 213-227.

Organisation for Economic Co-operation and Development - OECD. (2009). Patents as statistical indicators of science and technology. In Organisation for Economic Co-operation and Development - OECD (Ed.), OECD patent statistics manual. Paris: OECD Publishing.

Organisation for Economic Co-operation and Development - OECD. (2011). Invention and transfer of environmental technologies (OECD Studies on Environmental Innovation). Paris: OECD Publishing.

Platzer, M. D. (2012). US wind turbine manufacturing: federal support for an emerging industry (CRS Report for Congress). Washington: Congressional Research Service.

Sadorsky, P. (2021). Wind energy for sustainable development: driving factors and future outlook. Journal of Cleaner Production, 289, 125779.

Sahu, K. S. (2018). Wind energy developments and policies in China: a short review. Renewable \& Sustainable Energy Reviews, 81, 1393-1405.

Schleich, J., Walz, R., \& Ragwitz, M. (2017). Effects of policies on patenting in wind-power technologies. Energy Policy, $108,684-695$.

Tsai, Y.-C., Huang, Y.-F., \& Yang, J.-T. (2016). Strategies for the development of offshore wind technology for far-east countries: a point of view from patent analysis. Renewable \& Sustainable Energy Reviews, 60, 182-194.

Urban, F., Zhou, Y., Nordensvard, J., \& Narain, A. (2015). Firm-level technology transfer and technology cooperation for wind energy between Europe, China and India. Energy for Sustainable Development, 28, 29-40.

Valentine, S. V. (2011). Wind power politics and policy. Oxford: Oxford University Press.

Valentine, S. V. (2015). Japanese wind energy development policy: grand plan or group think? Energy Policy, 39, $6842-6854$.

Watson, S., Moro, A., Reis, V., Baniotopoulos, C., Barth, S., Bartoli, G., Bauer, F., Boelman, E., Bosse, D., Cherubini, A., Croce, A., Fagiano, L., Fontana, M., Gambier, A., Gkoumas, K., Golightly, C., Latour, M. I., Jamieson, P., Kaldellis, J., Macdonald, A., Murphy, J., Muskulus, M., Petrini, F., Pigolotti, L., Rasmussen, F., Schild, P., Schmehl, R., Stavridou, N., Tande, J., Taylor, N., Telsnig, T., \& Wiser, R. (2019). 
Future emerging technologies in the wind power sector: a European perspective. Renewable \& Sustainable Energy Reviews, 113, 109270. http://dx.doi.org/10.1016/j.rser.2019.109270.

World Intellectual Property Organization - WIPO. (2021). PCT Contracting states and two-letter codes. Retrieved in 2021, April 18, from https://www.wipo.int/export/sites/www/pct/en/list_states.pdf

Xibao, L. (2012). Behind the recent surge of Chinese patenting: an institutional view. Research Policy, 41, $236-249$.

Xu, J., \& Li, L. (2016). Wind energy generation technological paradigm diffusion. Renewable \& Sustainable Energy Reviews, 56, 436449. http://dx.doi.org/10.1016/j.rser.2015.12.271.

Yuan, J., Na, C., Xu, Y., \& Zhao, C. (2015). Wind turbine manufacturing in China: a review. Renewable \& Sustainable Energy Reviews, 51, $1235-1244$.

Zhang, B., \& Horvath, S. (2005). A general framework for weighted gene co-expression network analysis. Statistical Applications in Genetics and Molecular Biology, 4(1), e17. PMid:16646834.

Zhou, Y., Luckow, P., Smith, S. J., \& Clarke, L. (2012). Evaluation of global onshore wind energy potential and generation costs. Environmental Science \& Technology, 46(14), 7857-7864. PMid:22715929. 